\title{
STUDENTS' SUCCESS IN ENGLISH VOCABULARY ACQUISITION THROUGH MULTIMEDIA ANNOTATIONS SENT VIA WHATSAPP
}

\author{
Dr. Levent CETINKAYA \\ ORCID: 0000-0002-0167-4846 \\ School of Education \\ Canakkale Onsekiz Mart University \\ Canakkale, TURKEY \\ Dr. Selim Soner SUTCU \\ ORCID: 0000-0002-8875-5955 \\ Faculty of Science and Letter \\ Baskent University \\ Ankara, TURKEY
}

Received: 17/12/2018 Accepted: 21/02/2019

\begin{abstract}
The purpose of this study is to determine the effects of the multimedia annotations which were sent through instant messaging application WhatsApp on students' success in English vocabulary acquisition together with their opinions on the educational use of WhatsApp and the multimedia annotations. In the study, mixed method model, which combines both quantitative and qualitative data, was employed. Results of the variance analysis of the quatitative data indicated that the multimedia annotations sent through WhatsApp yielded a meaningful increase in students' vocabulary acquisition. Multiple comparison test to identify the reason of this increase revealed that 'Text+Picture+Audio' and 'Text+Picture' multimedia annotations increased students' vocabulary acquisition meaningfully when compared to other learning multimedia annotations. Although 'Text+Audio' multimedia annotation contributed to the success of students more than the students who received only 'texts', it wasn't found meaningful. In the qualitative aspect of the study, students expressed their willingness to go on the treatment. They stated that similar researches in their other courses could be useful. They also added that they could learn unconsciously and expressed positive opinions towards the use of the pictures and audio annotations in particular. However, a few students reacted negatively againts the irrelevant posts and stated that the posts occupied a lot of space on their phones.
\end{abstract}

Keywords: WhatsApp, instant messaging;, language learning, vocabulary acquisition, multimedia annotations.

\section{INTRODUCTION}

Internet and internet based technologies which are the popular topics that the today's students are most familiar with, have enabled them to reach the necessary competences to control their knowledge construction actively. These students state that they are bored of traditional methods and want to have more varied forms of communication (Oblinger, \& Hagner, 2005), use independent learning styles to learn better and make use of the benefits of technology (Carlson, 2005). Accordingly, social networking services (SNSs) and applications which have similar features, offer new possibilities for these modern requirements of new generations. SNSs, which are defined as softwares that facilitate the interaction between individuals and groups and support the formation of social relationships (Boyd, 2003), have become popular due to their nature to satisfy the needs of individuals to socialize. Though they are used informally, researches indicate that they have potential to be used to support educational activities and they have effects on different variables (communication, motivation, social interaction, academic success, etc.) depending on the way they are employed (Cetinkaya, 2017a). As stated by Sarwar, Zulfiqar, Aziz and Chandia (2018), SNSs serve as a dynamic tool to expedite the development of learning environments by encouraging cooperation and communication among students which reinforce their learning behavior and performance. 
The number of the users of social networking services, together with the introduction of their mobile versions, have increased rapidly soon after the popularity of smartphones. This process which started by commonly used web based social networking services (Facebook, Twitter etc.) in particular, began to be handled differently after the introduction of the messaging applications (WhatsApp, BBM, Line, etc.) which were specifically designed for mobile phones (Cetinkaya, 2017a). The most popular of these applications which have the most features of social networking services are instant messaging applications. WhatsApp which was developed for smartphones and tablets and aims to improve the communication in principle, offers picture, audio and video sharing and a number of useful features like forming groups by the help of which it has gained a large number of user groups. Its popularity among the users and its potential for language learning make it invaluable. The opportunity to access to different learning materials anytime and anywhere enhance students' learning and enable them to create their own knowledge (Amry, 2014).

The potential of social networking services which enable different cultures to interact with each other beyond the physical borders, raise the importance of language learning. Besides the basic skills, grammar and vocabulary of the target language should also be learnt (Demirel, 2015). When improvement of these skills are concerned, acquisition of vocabulary is often neglected and therefore it should be the central component of foreign language learning, and foreign language curricula should be designed accordingly (Folse, 2004; Lewis, 1993; Zimmermann, 1994). While a rich vocabulary repertoire will contribute to better usage of listening, reading and writing skills (Nation, 1995), its inadequacy and misuse of vocabulary lead to the breakdown of the communication (Allen, 1983). However, while without grammar very little can be conveyed, without vocabulary nothing can be conveyed (Wilkins, 1972) and therefore, learners carry around dictionaries and not grammar books (Schmitt, 2010). Accordingly, learning objectives (Ary, Jacobs, Sorensen, \& Walker, 2013; Bygate, Skehan, \& Swain, 2013; Fairclough, 2014; Fink, 2013; McLaughlin, 2013; Van Lier, 2014) and the learning environment should be carefully chosen when teaching language (Huffman, 2010; Wong, \& Looi, 2010). Hence, it could be useful to benefit from the potentials of new technologies and their accompanying new applications to supply different environments and materials. WhatsApp, in particular, which has the common features of a social networking services and is popular among the young people, should not be disregarded in language education. WhatsApp enables cooperative synchronous and asynchronous communication and can act as a channel in the transfer of the materials that can address to the learners' multiple senses. Today, we know that there are memory types which are integrated but different from each other, and for a high level learning and recall, different components of the memory should be used simultaneously (Sylwester 1995). Under certain circumstances, verbal material can evoke the construction of visual representations, and visual material can evoke the construction of verbal representations (Mayer, \& Sims, 1994). The more connections to a single idea or concept established, the more likely it is to be remembered (Huitt, 2003). Accordingly, when teaching new vocabulary, connections that are interrelated and that can address to multiple senses must be established and these connections should be transferred to the learners via appropriate channels.

The more the educational contents are developed SNSs which are already adopted by many people, the more their potential to influence education increases. Accordingly, their integration into education should be completed and thus their potential can be utilised. This potential which enable cooperative synchronous and asynchronous communication together with their multimedia support and cover the features of social networking services on a large scale, should not be disregarded. Though, yet it is early to know the effects of WhatsApp on education, the researches on SNSs so far reveal its potential. Their great impact on the social development of the young people in particular, necessitates the determination of their effects on their academic development and their expectations as well (Cetinkaya, 2017a). Therefore, this study aims to determine the effects of the multimedia annotations sent through instant messaging application WhatsApp on students' success in English vocabulary acquisition and their opinions on the educational use of WhatsApp and the multimedia annotations. In line with this purpose, answers to the following question have been sought;

1. Is there a significant increase in the success scores of students' vocabulary acquisition after sending the multimedia annotations through WhatsApp?

2. Is there a significant difference between the success scores of students' vocabulary acquisition depending on the types of multimedia annotations sent through WhatsApp?

3. What are students' opinions on the educational use of WhatsApp and the multimedia annotations? 


\section{METHODOLOGY}

\section{Research Model}

This research, which aims to determine the effects of the multimedia annotations which were sent through WhatsApp on students' vocabulary acquisition success and their opinions on the educational use of WhatsApp and the multimedia annotations, employs mixed methods model. The mixed method, which is defined as the combination of qualitative and quantitative methods, can take advantage of the strengths of both qualitative and quantitative research methodologies and overcome the limitations of each method (Creswell, 2003; Creswell, \& Plano Clark, 2007; Johnson, \& Christensen, 2008; Tashakkori, \& Teddlie, 2003). Particularly, sophistication of social facts necessitates bringing different methods together and observing them in order to be able to explain them thoroughly (Creswell, et al., 2003). Accordingly, in this study, explanatory mixed method was employed.

In explanatory mixed method design, during which the quantitative data are collected and analysed before the qualitative data, the researcher uses qualitative data to examine the results of the quantitative data throughly (Creswell, 2005). Within this framework, in order to determine the effects of the types of the multimedia annotations sent through WhatsApp to teach English vocabulary, pretest-posttest control group quasi-experimental design which forms the quantitative aspect of the study and $4 \mathrm{X} 2$ split plot design was used. In quasi-experimental design which is described as the best research design that explains the causeeffect relationships between the variables, the treatment is performed after the pretest and at the final stage, posttest is given to determine the effect on dependent variable (Fraenkel, \& Wallen, 2011). In 4X2 split plot design, which was designed to test the effect of the types of the multimedia annotations, first factor predicates four different multimedia annotations (Text, Text+Audio, Text+Picture, Text+Picture+Audio), whereas second factor predicate pretest and posttest measurements. The research design is given in Table 1.

Table 1. Research design view

\begin{tabular}{lcc}
\hline Pre experimental & \multicolumn{1}{c}{ Experimental process } & Post experimental \\
\hline PreTest (AT) & WhatsApp Multimedia Annotations & PostTest (AT) \\
\hline AT: Achievement Test & \\
Independent variables: Multimedia annotations sent via WhatsApp & \\
Dependent variables: Success in English vocabulary acquisition &
\end{tabular}

For the qualitative aspect of the research, case study was used. Qualitative research is an approach that uses inductive attitude in social studies and underlines descriptive data collection technique in natural environments and the views of the participants (Bogdan, \& Biklen, 2006). As for case study, it tries to reveal present examples of application by using the question 'how' (Yildirim, \& Simsek, 2008). In this part of the research, students' opinions on the educational use of WhatsApp and the multimedia annotations were taken.

\section{Study Group}

Criterion sampling which is one of the purposive sampling methods was utilized in determination of the participants of the research which was carried out with secondary education 9th grade students (aged between 14-15). In line with the aim of the study, the continuity of experimental processes, the ease of accessibility to participants, the proximity of prior knowledge levels of the students to each other and the available technological infrastructure were taken into consideration while forming the study group. 9th. grade students in 4 classes who took English courses from the same teacher participated in the study. 112 students had smartphones but, though 3 students had smartphones, they didn't have WhatsApp application on their phones. According to the prior knowledge gained from the students, the students who met technical requirements considerably were informed about the purpose of the research and were asked if they wanted to participate in the research. It was noted that the students who didn't have WhatsApp on their phones also 
wanted to participate in the study, so they could participate in the study after they installed WhatsApp on their mobile phones. The study started with pretest which was given to 112 students, 59 girls (\%52.6) and 53 boys (\%47.3), ended with the qualitative data that were gathered by open-ended question forms after the posttest.

\section{Implementation Phase}

The face to face education process of the students in the study group of the research was performed by the same teacher within the framework of the common curriculum. When sending the vocabulary items with multimedia annotations to the students, no additional interferences have been made by the researcher.

\section{Choosing English Words and Creation of the Achievement Test}

72 Words in equal numbers $(\mathrm{N}=18)$ for each type of multimedia annotations were determined to be included in the study from the vocabulary parts of students' 11 th grade English course book in consultation with their instructors. Together with the multimedia annotations, the achievement test which consisted of 72 multiple questions was formed by using the words determined, in parallel to the 10th grade curricula. Before the pilot testing, it was reviewed in terms of clarity and appropriateness for course outcomes by three high school English instructors, two academicians of English language education and one academician of educational technology. After the review of the experts, item analysis of the questions, which have content validity, was done with 87 students of 11 th grade classes in the same school which the study would be conducted. In the first form of the test which consisted of 72 questions, ' 1 ' point for each correct answer, ' 0 ' point for each wrong or blank answer was given. In order to examine the internal consistency between the test scores, since the responses to test items were 1/0, Kuder Richardson-20 (KR-20) reliability was used, and the correlation between scores of the test items and the total score of the test was calculated by item total score correlation. It is stated that the items which have item total correlation value .30 and higher are said to discriminate between the individuals well and test reliability co-efficient value .70 or higher is found adequate for the reliability of the test scores (Fraenkel, \& Wallen, 2011; Nunnally, \& Bernstein, 1994). After the analysis, 5 items whose item total correlation value is . 30 and lower were omitted and an achievement test that has 64 items was formed begining with the questions that have the highest item total correlation. The reliability of the achievement test, which consisted of equal number of questions $(\mathrm{N}=16)$ in information packs and have total item correlations between .42-.84, was calculated to be .87 (KR-20).

\section{Creation of Multimedia Annotations}

When forming the messages to be sent via WhatsApp, decision on how each word would be annotated was given by asking the opinions and approval of three high school teachers, two academicians of English language and literature, one academician of Turkish language and literature and two academicians of educational technology. Multimedia annotations were formed in three stages: determining the text content, the pictures, and formation of the audio files.

1. Texts, together with the words themselves, included 'English description', 'Turkish equivalent' and 'a sample sentence in English'. Text contents have also been effective when choosing the words that would include picture and audio files.

2. Pictures were carefully chosen to support the text. Moreover, special attention was given to the quality and the size of the pictures and also the consistency of their messages with the words to be taught. Accordingly, after having the consensus of the experts, the most suitable 32 pictures were choosen.

3. Audio files were created by using a special microphone and an audio program. The words to be taught were pronounced by an academician of English language and literature who has expertise in phonetics, and the most suitable ones were chosen in accordance with the opinions of two academicians from the same field. 


\section{Sending the Words with Multimedia Annotations}

A total of 64 messages, each consisting of 16 'text', 'text+audio', 'text+picture' and 'text+picture+audio' which were chosen by expert views, were sent randomly one by one per day. The messages, which were determined by the agreement of experts, were sent during the day at random times between 08:30-21:30 by the researcher. Annotated words were sent simultaneously in the order of 'English text' then 'picture' and 'audio' file if available. Picture and audio files were formatted and resized suitable for WhatsApp and no problems were encountered while sending, receiving and opening the files. Moreover, by the help of check marks, which is a practical feature of WhatsApp that lets the users know the messages have been read, all the messages sent to the participants could be tracked and confirmed that they were received and read by the participants.

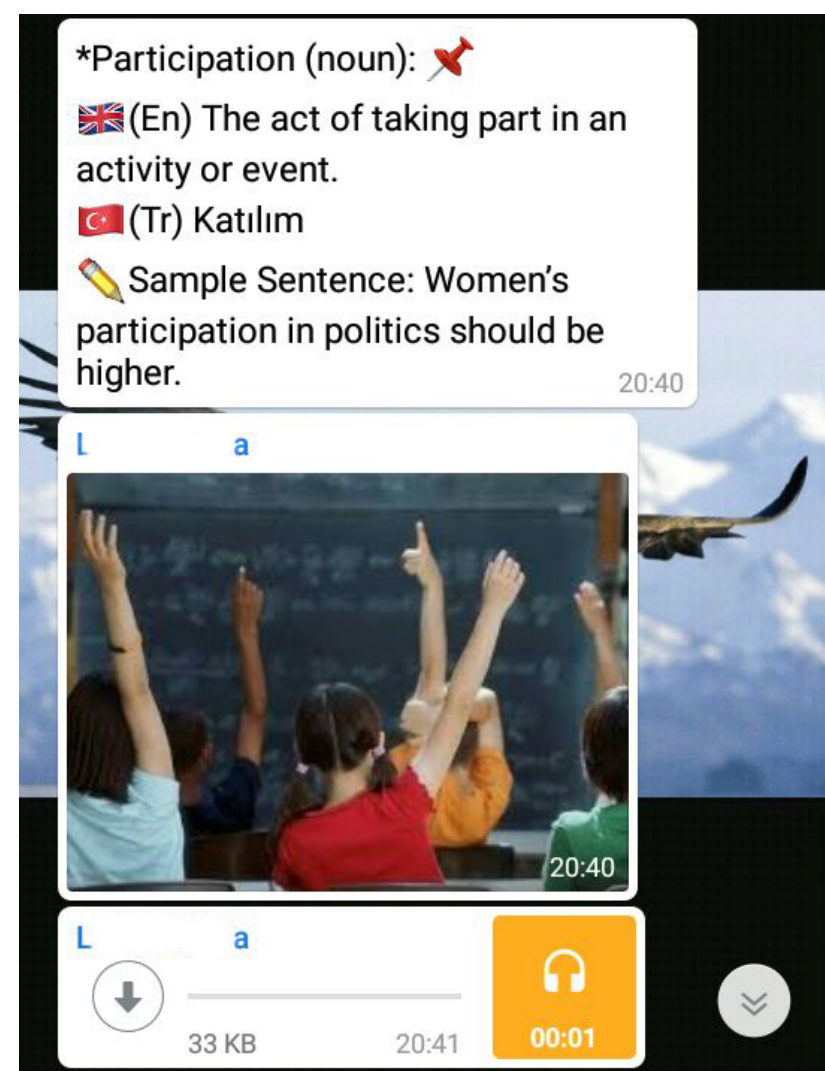

Figure 1. Sample message
1. Text
a. English word
b. English definition
c. Turkish equivalent
d. A sample sentence in English

2. Supportive picture

3. Supportive audio file

As seen in WhatsApp screenshot in Figure 1, together with the text content (English definition, Turkish equivalent, and sample sentence in English), supportive materials (picture, audio or both), if available, were sent simultaneously.

\section{Data Collection}

The quantitative data of the study were collected by using an achievement test consisting of (five choice) multiple choice questions before and after the implementation. After the analysis of the data obtained through the achievement test which consisted of 70 questions determined by analysis and expert reviews, messages were sent. The study groups were formed after the analysis of the data from the achievement test. The messages started to be sent in a period of 64 days, one week after the pretest, and it was followed by posttest one week after this period. Achievement tests were conducted within an interval of approximately 79 days to all students concurrently under the supervision of 3 teachers and 2 researchers in the classroom. Same questions were used and evaluated in both tests. 
Qualitative data were collected by open-ended question form one week after the posttest was given to 112 students in the study group. The students were informed before the open ended question forms and they were asked to answer the research question; 'Write your opinions about the process of learning new words through WhatsApp and the contents of the messages, if any'. The question to determine their opinions regarding the implementation process and the multimedia annotations was given to the students by their teachers to be replied in written form in the classroom in order to enable them to give detailed answers.

\section{Analysis of the Data}

In order to determine the effects of four different multimedia annotations on the increase of students' success, Cohen's d effect size was calculated. Effect size is a statistical value which shows to what extent the researched phenomenon exists in the results of the study independent of sample size and the results of statistical tests (Sanchez-Meca, \& Marin-Martinez, 2010), and the level of deviation from the expectations defined in the null hypothesis of the results obtained from the sample (Cohen, 1994; Vacha-Haasse, \& Thompson, 2004). A commonly used interpretation is to refer to effect sizes as small $(\mathrm{d}=0.2)$, medium $(\mathrm{d}=0.5)$ and large ( $\mathrm{d}=0.8)$ based on benchmarks suggested by Cohen (1988). Cohen's $\mathrm{d}$ is determined by calculating the mean difference between your two groups, and then dividing the result by the pooled standard deviation (Cohen's d=(M2-M1) SDpooled). Before the comparison test which was planned to find the effect of the multimedia annotations in vocabulary teaching, groupXsuccess common effect was checked and found insignificant $(F(3,56)=1.746, p>.05)$. This finding showed that the slopes of regression lines, which were calculated for the interpretation of students' success depending on four types of multimedia annotations, were equal. However, pretest results of the words which were grouped according to the annotation types, showed that their variance was equal $(\mathrm{F}=2.576, \mathrm{p}>.05)$ and the data showed normal distribution among all groups $(\mathrm{P}>.05)$. Analysis also showed that there was a positive and linear relation between the dependent variable posttest and the common variable pretest $(\mathrm{t}=30.689, \mathrm{p}=.000)$. Since all the assumptions were met, in order to determine the effect of the multimedia annotations on English vocabulary teaching, single factor covariance (ANCOVA) was performed during which pretest scores were held as control variable. In order to find out the difference that arouse because of the multimedia annotations types, Bonferroni multiple comparison test which is one of the post-hoc tests, was performed.

During the qualitative aspect of the study, the written data obtained from the students by open ended questions, were analysed by using content analysis types; categorical analysis and frequency analysis. During the categorical analysis, the stages of coding of the data, formation and organisation of categories, defining and interpreting the findings were followed (Corbin, \& Strauss, 2007). Frequency analysis revealed the quantitative frequency of the data, thus determining the density and the importance of a particular factor (Ryan, \& Bernard, 2000; Tavsancil, \& Aslan, 2001). Hence, the qualitative data were digitalised and their reliability increased, biasness decreased and comparison of the data was enabled (Yildirim, \& Simsek, 2008). Furthermore, screenshots of students' posts were given as they are when necessary, which ensured conclusiveness (Wolcott, 1990) and the research questions were supported.

\section{FINDINGS AND INTERPRETATIONS}

The findings are given below in the order of research questions and methodologies.

\section{Findings for Quantitative Data}

In order to determine the effects of multimedia annotations on students' success in English vocabulary learning, Cohen's $\mathrm{d}$ effect size was calculated and the effect sizes of the multimedia annotations are given in table 2. The results of the data analysis after the post-test, indicated that the multimedia annotation which included text+picture+audio had the highest and large effect size value $(\mathrm{d}=1.037)$. It was followed by text+picture annotation with a medium effect size $(\mathrm{d}=0.618)$. However, the text+audio annotations $(\mathrm{d}=0.287)$ were found to be higher than only text annotation $(\mathrm{d}=0.262)$ both having small effect sizes. Consequently, it can be inferred that adding 'audio' to 'text' is effective in the increase of success but adding 'picture' to the content contributed to the success much more than the audio file. 
Table 2. Descriptive statistics of multimedia annotations according to their content and their effect sizes

\begin{tabular}{lccccccccc}
\hline & & & \multirow{2}{*}{ Pretest } & & Posttest & & $\begin{array}{c}\text { Corrected } \\
\text { Posttest }\end{array}$ & Effect size \\
\hline Multimedia Annotation Types & $\mathrm{N}$ & Mean & $\mathrm{S}$ & Mean & $\mathrm{S}$ & & Cohen's d & Level \\
\hline 1. & Text & 16 & 44.75 & 35.48 & 54.00 & 35.19 & 53.39 & 0.262 & Small \\
2. & Text+Audio & 16 & 42.75 & 38.07 & 53.38 & 35.88 & 54.63 & 0.287 & Small \\
3. & Text+Picture & 16 & 45.75 & 32.29 & 64.81 & 29.31 & 63.27 & 0.618 & Medium \\
4. & Text+Picture+Audio & 16 & 43.13 & 24.70 & 67.56 & 22.36 & 68.47 & 1.037 & Large \\
\hline & Total & 64 & 43.98 & 32.34 & 59.94 & 31.40 & & & \\
\hline
\end{tabular}

Single factor covariance (ANCOVA) analysis was performed to see whether the difference which was observed between the contents of the multimedia annotations and success test mean scores was significant and to determine their effect on teaching English vocabulary. After all the assumptions were met, students' corrected posttest mean scores were examined depending on the contents of multimedia annotations. The corrected success test mean scores in Table 2 showed that the success was highest in words with text+picture+audio annotations and it was followed by the words with text+picture, text+audio and text annotations respectively. The results of the single factor covariance (ANCOVA) analysis to see whether the difference between the corrected success mean scores of the groups are given in Table 3.

Table 3. ANCOVA statistics for the observed difference between the corrected success test mean scores

\begin{tabular}{lrrrrrrl}
\hline \multicolumn{1}{c}{$\begin{array}{c}\text { Source of } \\
\text { Variance }\end{array}$} & Sum of Square & sd & Mean Square & \multicolumn{1}{c}{$\mathrm{F}$} & $\mathrm{p}$ & $\mathrm{\eta} 2$ & $\begin{array}{l}\text { Significant } \\
\text { Difference }\end{array}$ \\
\hline Pretest & 56995.073 & 1 & 56995.073 & 2629.065 & $.000^{*}$ & $1-3,1-4$ \\
Group & 2478.575 & 3 & 826.192 & 38.111 & $.000^{*}$ & .660 & $2-3,2-4$ \\
Error & 1279.052 & 59 & 21.679 & & & & $3-4$ \\
\hline Total & 60837.750 & 63 & & & & & \\
\hline
\end{tabular}

${ }^{*} p<.05$

The results show that there is a significant difference between students' posttest mean scores which were corrected according to their pretest scores $(\mathrm{F}(3,59)=38.111, \mathrm{p}<.05)$. This finding indicates that the multimedia annotations have different effects on the success of students. Furthermore, the magnitude of the effect size $(\eta 2=.660)$ of the multimedia annotation content on success, which is the dependent variable, shows that the significant difference between the means is also great (Cohen, 1988). This also shows that $66 \%$ of the differences in the scores of posttest derived from the contents of the multimedia annotations sent via WhatsApp. In order to make comparisons to determine the source of this difference, Bonferroni multiple comparison test which is one of the post-hoc test statistics was performed. According to the results, the difference between the corrected success mean scores of the vocabulary items which were annotated with 'Text' and 'Text+Audio', and 'Text+Picture' and 'Text+Picture+Audio' was found meaningful ( $\mathrm{p}<.05)$. However, no significant difference was found between the corrected success mean scores of the vocabulary itens which were annotated with 'Text' and 'Text+Audio' ( $p>.05)$. The findings revealed that the English vocabulary items which were annotated with 'Text+Picture+Audio' and 'Text+Picture' increased students' vocabulary acquisition significantly when compared with the other multimedia annotation types. Although 'Text+Audio' annotations contributed to the success of the students more than only 'Text' annotation, this increase was not found to be meaningful. While it seems possible to allege that the Picture annotations have been effective in the increase of vocabulary acquisition success significantly, it has not been the same for audio annotations. These results which are in parallel with the effect size analysis support that addition of audio to text is effective in the increase of success, but addition of picture is more effective.

\section{Findings for Qualitative Data}

Students' opinions on the process of learning new words through WhatsApp were collected by open ended question forms. The findings, which were obtained by written data and analysed by using content analysis types, categorical analysis and frequency analysis, are given in Table 4. Furthermore, students' own expressions (S+student code) are also given in this section. 
Table 4. Students' opinions on the process of learning new words through whatsapp and the multimedia annotations

\begin{tabular}{lll}
\hline Positive & $f$ & $\%$ \\
\hline Willingness to go on the treatment & 90 & 80.4 \\
Willingness to have the same treatment in their other courses & 67 & 59.8 \\
Realization of learning (consciously or unconsciously) & 60 & 53.6 \\
Sending the pictures with texts & 59 & 52.8 \\
Sending Picture and Audio files with the Texts & 31 & 27.7 \\
\hline Negative & 21 & 18.8 \\
\hline Irrelevant messages within the group & 20 & 17.9 \\
Storage space problems in smartphones & \\
\hline
\end{tabular}

These rates which are attained after the analysis of qualitative data and students' opinions (one or more) about the process of learning new words through WhatsApp and the contents of the messages indicate that students' positive opinions outweigh their negative opinions. The data which were collected after all messages were sent, show that majority of the students didn't want the process to end. S104's statement that 'The messages should keep coming, it would be wonderful if we receive such messages in our other courses as well reflect the opinions of many other students. One of the most important reasons that is effective in students' willingness is the realization of learning which is expressed clearly by S13 'I could learn many words like this which I didn't know before. For me, these messages should keep coming'. Some of the statements of the students as also expressed by S68 'I noticed that I had learnt new words without any special effort after the exam' indicate that learning could take place unconsciously. Besides the positive opinions, the most emphasized point about the contents of the messages were the pictures in them. As expressed by S7 'some pictures in particular have been very helpful in learning some English words', S79 'pictures helped me remember the words easily.' and S33 'I wish they all had pictures', words annotated with pictures were welcomed by students warmly. S21's words; 'receiving both text and picture was very good' and S17 'By the help of audio files I could learn their pronunciations as well. In fact, they all could have contained audio files.' also show students' positive attitude towards the process. However, that the pictures are more emphasized than the audio files in students' expressions is remarkable.

On the other hand, some students, though in limited number, expressed some negative opinions as well. As mentioned by S110 'it could have been better if there weren't any unnecessary posts by some of our friends', some students got annoyed by the irrelevant posts within the group. However, as stated by S83 '... sent some off-topic posts. But they quitted after they were warned by some of my friends and I', such problems were resolved without the intervention of the researcher. But S19 stated that she found a different solution to this problem; '... sent some off-topic messages and I silenced the group in return'. Another negative point that is stated by the students is the size of the messages. As stated by $S 97$ 'picture and audio files filled up the memory of my phone', memory space was reported as a problem by some students. As a solution to this problem, a few students reported that they freed up space by deleting some of the picture or audio files which is also summarised by S41 'I had to delete andio files because they occupied space'.

\section{RESULT}

The results obtained from the study which utilised mixed method model and aimed to determine the effects of the multimedia annotations sent through instant messaging application WhatsApp on students' success in English vocabulary acquisition and their opinions on the educational use of WhatsApp and multimedia annotations are discussed within the related literature, and recommedations that emerged accordingly are given under headings.

\section{Results Related to Quantitative Data}

The calculations to determine the effects of four different mutimedia annotations on students' success in English vocabulary learning showed that the effect size of the multimedia annotations depending on their content was highest and at the level of 'large' in the Text+Picture+Audio annotations while Text+Picture annotations had the effect level of 'medium'. Although Text+Audio annotations had a higher effect, the 
effect of both multimedia annotations were at 'small' level. Accordingly, it can be inferred that while adding audio to text is effective in the increase of success, adding picture to the content contributed to the success much more than the audio file. As a result of the analysis, which was performed to test the effectiveness of the multimedia annotations on students' vocabulary acquisition success and to see whether there is a significant difference between them, it was found that there is a significant difference between multimedia annotations and the corrected posttest mean scores. The result that $66 \%$ of the difference between the posttest scores of the multimedia annotations originated from the contents of multimedia annotations that were sent via WhatsApp shows that the multimedia annotations are strong determinants of the success. Multiple comparison test to identify the source of this difference, revealed that 'Text+Picture+Audio' and 'Text+Picture' annotations increased students' vocabulary acquisition success meaningfully compared to other annotations. Although 'Text+Audio' annotations contributed to the success of the students more than the only text annotation, this increase was not found to be meaningful. While it seems possible to allege that the multimedia annotations which contain picture have been effective in the increase of vocabulary acquisition success significantly, it has not been the same for audio files. These results which are in parallel with the effect size analysis support that while addition of audio file to text file is effective in the increase of success, addition of picture to the content is more effective. These results are also in parallel with the results of the study conducted by Sadeghi and et.al (2016) in which they compared the effectiveness of different content types (text+picture, text+audio, and text+picture+audio) on students' English reading skills and vocabulary acquisition. In this research, it is determined that 'Text+Picture+Audio' annotations were more effective than 'Text+Audio', and while 'Text+Audio' annotations were the least effective, in any case the content is more effective when supported by multimedia annotations than its single form.

The results of the study indicate that supporting the texts with picture and audio annotationss contribute to the acquisition of vocabulary. As also often discussed in the literature, the results of the researches into the use of multimedia in learning indicate that supporting the texts with visual and aural materials could contribute to the acquisition of knowledge. This was also supported by theoretical basis (Limited capacity, dual coding, multimedia learning etc.) and tested in many researches.

At this point, the dual coding theory, which is one of the cognitive learning approaches, suggests that environmental perceptions are coded in two different areas of the mind depending on whether they are verbal or non-verbal, and that the process of meaning takes place in these two areas either within themselves or as the result of relations between them (Paivio, 2006). Again, according to this theory, it is necessary to correctly perceive the differences between verbal and nonverbal codes and to correctly attach and associate them with the mind in order to obtain correct meanings (Sadoski, \& Paivio, 2004). Media bring a slice of real life into the classroom, provide a density of information and richness of cultural input not otherwise possible in the classroom, they can help students process information and free the teacher from excessive explanation (Cameron, 2001). In her study Ulitsky (2000) state that exploiting multiple modalities for developing comprehension was seen as a very effective learning strategy-using aural, visual and textual cues to predict, to guess, to preview, or to check understanding of the storyline. Similarly, Hu and Deng (2007) reported that multimedia boosts students' word recognition ability because the transfer of information by using auditory and visual media excite students' attention and hence the retention of the words increases. Davies and Pears (2000) emphasize that new items are not learned simply after having been presented or practiced a few times; new words should be presented in a context, with key models. In his study which he investigated the effects of multimedia annotations on incidental vocabulary learning and reading comprehension of advanced learners of english as a foreign language, Akbulut (2007) discovered that the students who accessed to pictures, video clips and texts got higher scores than the students who only accessed to texts. Sylwester (1995) stated that the information which is also coded visually would be more lasting than when it is coded only verbally. Mayer (2001) reported that people learn better from words and pictures than from words alone and that multimedia could be used as a visual assist to clarify the meaning. Sadeghi and Farzizadeh (2013) found that teaching vocabulary through visual aids helped learners gain more in vocabulary learning. Jones (2004) investigated students' recognition and recall of L2 vocabulary items using pictoral and written items and revealed that the group who were supported by pictures and written texts outperformed the group who were supported by only written text. Similarly, Mansourzadeh (2014) conducted a comparative study of teaching vocabulary through pictures and audio-visual aids to young Iranian EFL learners and found that though they both contributed to the success, pictures were more effective than audio-visyal aids. In Cetinkaya (2017b)'s study which examined the use of WhatsApp in literature lesson, 
information packs which included text and text+picture were sent to the students, and a significant increase in the success of the students were observed at the end of the study. Similarly, the results of the study which was conducted by Cetinkaya and Sutcu (2018) and aimed to determine the use of Facebook and WhatsApp applications in English language learning and compared students' success show that social networking services can be used as an effective assistive technology in learning English vocabulary. In the study, WhatsApp has been found more effective in the increase of students' success compared to Facebook. Also in the study, researchers suggest that the advantage offered by the multimedia support of these social network services be benefitted and emphasize that these services could be used as natural educational technologies.

\section{Results Related to Qualitative Data}

After the use of open-ended question form, the data, which were taken in written form, were analysed by using content analysis, and students' opinions on the educational use of WhatsApp and multimedia annotations. The analysis of the students' opinions showed that the rate of the positive opinions stated by the students was higher than the negative opinions. Students' demand to go using the annotations not only in their English courses but in their other courses as well, is quite remarkable. Another important point which was often stated by the students is that with their approval of the process, their motivation increased and learning realized. Plana and et.al (2013) used WhatsApp in language teaching and found that instant messaging application increased students' motivation and their willingness to read in a foreign language. In their study Mistar and Embi (2016) concluded that students showed a very positive attitude towards the use of WhatsApp as a learning tool and that they adopted it as a learning tool and did not want to give up using it in their English courses. Smit (2012) also stresses the potential of instant messaging applications in increasing learning. All these previous studies together with the results of this study emphasize the fact that instant messaging applications could contribute to students'success and students are inclined to adopt them in their learning. Accordingly, it seems possible to say that there is a correlation between adoption of the application and success. Another positive point stated by the students which could be directly or indirectly related is the multimedia support of the application. It is noted that pictures sent with texts through WhatsApp, also the audio files, though to a lesser extent, were welcomed by students and were effective in their learning. This is also in line with This effect is also supported by the results concerning students' success in the acquisition of English vocabulary in the quantitative part of this study.

The most important negative point that the students expressed about process was the irrelevant messages and posts by the group members. Although all the participants of the study were informed about the aim of the study, there were some irrelevant messages within the group which were later resolved by the group members as also was mentioned in his study by Cetinkaya (2017a). Similar problems were also reported in other studies towards the use of WhatsApp in learning and also was added that students overcame the problem by silencing the group (Bouhnik, \& Deshen 2014; Cetinkaya, 2017a). In other studies, conducted on the use of social networking services and mobile devices in education, it is reported that these irrelevant messages within the group could influence the students negatively and even cause them to lose their attention (Ex. Kusnekoff, Munz, \& Titsworth, 2015; McCoy, 2013, 2016). Another negative point reported by the students is the storage capacity of their mobile device. It was determined that a few students resolved the problem by deleting some picture or audio files. In his study on the use WhatsApp, Cetinkaya (2017a) reports that these problems are often underlined in the studies about the use of mobile devices in education and that they could inhibit the use of these mobile devices effectively.

\section{DISCUSSION AND RECOMMENDATIONS}

When both the quantitative and qualitative findings are evaluated together, it could be concluded that the use of WhatsApp application in vocabulary learning contributes to success and this contribution could be directly related with the multimedia annotations that are sent to the students. Though the picture and audio files which are sent together with the texts, contributed to the learning, particularly pictures that are relevant to the texts increased the success meaningfully. Furthermore, students welcomed the process of receiving the multimedia annotations warmly to a large extent. WhatsApp application also plays an important role in the transfer of the annotations as well as their formation effectively. The transfer of the information using appropriate channels is as important as the design of the information properly. These findings all indicate 
that the benefits which WhatsApp application may offer, which has become one of the most common applications in smartphones and does not need any training to use, should be considered. It is suggested that further studies should concentrate on the following points:

- The use of WhatsApp in English vocabulary learning should be encouraged.

- The contents which contain annotations should be provided in groups to students.

- Pictures to be sent should be relevant to the English vocabulary items.

- Similar studies that investigate the effect of WhatsApp on learning in other courses as well should be made.

- Studies on the use of other multimedia annotations (audio, video, animation etc.) which are supported by WhatsApp should also be conducted and their results be compared.

- Experimental studies should be conducted to verify the results based on the qualitative data obtained from the opinions of students.

\section{LIMITATIONS AND FUTURE IMPLICATIONS}

There are some limitations of the study which present a theoretical framework and empirical evaluations in the direction of the findings obtained. First, since it is a quasi-experimental study, it is carried out on a limited number of students. Although all statistical results in the study show that the group is suitable, this may limit the generalizability of the results of the study. The second limitation is that the study was conducted with certain English words and preferred content (text, picture and sound) accordingly. Although it is the right approach, the appropriateness of content and the management of the process that will be preferred in future studies may yield different outcomes. Another limitation is the fact that whether the multimedia annotations that are sent to students are read by the students or not. This is limited to the double blue ticks feature of whatsApp which informs that the message has been read by the recipients. At this point it is suggested that the researchers should make a good planning by considering factors such as the characteristics of the working group, determination of the content properly and process management.

\section{BIODATA and CONTACT ADDRESSES of AUTHORS}

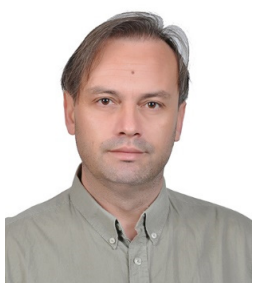

Dr. Levent CETINKAYA, is a fulltime assistant professor at the Department of Computer Education and Instructional Technology, Canakkale Onsekiz Mart University. Dr. Cetinkaya completed his Ph.D. in Educational Technology at Ankara University in 2013. His academic interest areas are mainly focused on use of technology integration in education, adaptive learning environments, distance education and social media, cyber behaviors and use of internet in education. He has papers published in both national and international indexes.

Levent CETINKAYA

Adress: Canakkale Onsekiz Mart Universitesi Anafartalar Kampusu Egitim Fakultesi Bilgisayar ve Ogretim Teknolojileri Egitimi Bolumu, B2 Blok, 17100, Merkez/Canakkale, Turkey

Phone: +9002862200200

E-mail: lcetinkaya@comu.edu.tr

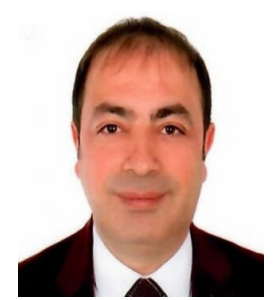

Dr. Selim Soner SUTCU, is a fulltime assistant professor at the Department of Translation and Interpretation, Baskent University. Dr.Sutcu completed his MA in Educational Technology at Ankara University in 2006. He gained his Ph.D. in Educational Technology at Ankara University in 2014. His academic interest areas are mainly focused on use of educational technologies and language learning (CALL), Learning Objects, Distance Education and Social Media. He has papers published in both national and international indexes.

Selim Soner SUTCU

Adress: Baskent University, Faculty of Science and Letters, Fatih Sultan Mahallesi Eskisehir Yolu 18.km 06790, Ankara, Turkey

Phone: +9031224666 66

E-mail: ssoner@baskent.edu.tr 


\section{REFERENCES}

Akbulut, Y. (2007). Effects of multimedia annotations on incidental vocabulary and reading comprehension of advanced learners of English as a foreign language. Instructional Science, 35(6), 499-517. doi: https://doi.org/10.1007/s11251-007-9016-7

Allen, V. F. (1983). Techniques in teaching vocabulary. Oxford: Oxford University Press.

Amry, A. B. (2014). The impact of whatsapp mobile social leaming on the achievement and attitudes of female students compared with face to face learning in the classroom. European Scientific Journal, 10(22), 116-136. Retrieved from http://eujournal.org/index.php/esj/article/view/3909/3700

Ary, D., Jacobs, L., Sorensen, C., \& Walker, D. (2013). Introduction to research in education (9th ed.). Indepence, KY: Cengage Learning.

Bogdan, R. C., \& Biklen, S. K. (2006). Qualitative Research for Education to Theory and Methods (5th ed.). Boston: Allyn \& Bacon.

Bouhnik, D., \& Deshen, M. (2014). WhatsApp goes to school: Mobile instant messaging between teachers and students. Journal of Information Technology Education: Research, 13, 217-231. Retrieved from http://www.jite.org/documents/Vol13/JITEv13ResearchP217-231Bouhnik0601.pdf

Boyd, S. (2003). Are you ready for social software? [Blog post]. Retrieved from http://www.stoweboyd.com/ post/2325281845/are-you-ready-for-social-software

Bygate, M., Skehan, P., \& Swain, M. (2013). Researching pedagogic tasks: Second language learning, teaching, and testing. London, UK: Routledge.

Cameron, L. (2001). Teaching languages to young learners. Cambridge: Cambridge University Press.

Carlson, S. (2005). The net generation goes to college. The Chronicle of Higher Education, 52(7), A34-A37. Retrieved from http://www.chronicle.com/article/The-Net-Generation-Goes-to/12307

Cetinkaya, L. (2017a). An educational technology tool that developed in the natural flow of life among students: WhatsApp. International Journal of Progressive Education, 13(2), 29-47. Retrieved from http://files.eric.ed.gov/fulltext/EJ1145590.pdf

Cetinkaya, L. (2017b). The impact of whatsapp use on success in education process. The International Review of Research in Open and Distributed Learning, 18(7), 59-74. DOI: http://dx.doi.org/10.19173/ irrodl.v18i7.3279

Cetinkaya, L., \& Sutcu, S. S. (2018). The Effects of Facebook and WhatsApp on Success in English Vocabulary Instruction. Journal of Computer Assisted Learning, doi: https://doi.org/10.1111/jcal.12255

Corbin, J. M., \& Strauss, A. C. (2007). Basics of qualitative research: Techniques and procedures for developing grounded theory. Thousand Oaks, CA: Sage.

Cohen J. (1988). Statistical Power Analysis for the Behavioral Sciences (2th ed.). Hillsdale, NJ: Lawrence Earlbaum Associates.

Cohen, J. (1994). The earth is round (p<.05). American Psychologist, 49(12), 997-1003. doi: https://doi. org/10.1037/0003-066X.49.12.997

Creswell, J. W. (2003). Research design: Qualitative, quantitative, and mixed methods approaches. (2th ed.). Thousand Oaks, CA: Sage.

Creswell, J. W. (2005). Educational research: planning, conducting, and evaluating quantitative and qualitative research (2nd ed.). New Jersey: Merrill Prentice Hall.

Creswell, J. W., \& Plano Clark, V. L. (2007). Designing and conducting mixed methods research. Thousand Oaks, CA: Sage.

Creswell, J. W., Plano Clark, V. L., Gutmann, M. \& Hanson, W. (2003). Advanced mixed- methods research designs. In A. Tashakkori \& C. Teddlie (Eds.), Handbook of mixed methods in social and behavioral research (pp. 209-240). Thousand Oaks, CA: Sage.

Davies, P., \& Pears, E. (2000). Success in English teaching. Oxford: Oxford University Press. 
Demirel, O. (2015). Egitimde Program Gelistirme (24. baski) [Curriculum Development in Education (24th. ed.).] Ankara: PegemA.

Fairclough, N. (2014). Critical language awareness. London, UK: Routledge.

Fink, L. D. (2013). Creating significant learning experiences: An integrated approach to designing college courses. John Wiley \& Sons.

Folse, K. S., (2004). Vocabulary Myths: Applying second language research to classroom teaching. University of Michigan Press: Ann Arbor.

Fraenkel, J. R., \& Wallen, N. E. (2011). How to design and evaluate research in education (8th ed.). NY: McGraw-Hill Higher Education.

Hu, H-p., \& Deng, L-j. (2007). Vocabulary acquisition in multimedia environment. USChina Foreign Language, 5(8), 55-59. Retrieved from http://citeseerx.ist.psu.edu/viewdoc/ download?doi=10.1.1.116.5159\&rep=rep1\&type=pdf

Huffman, S. R. (2010). The influence of collaboration on attitudes towards English vocabulary learning. Graduate Theses and Dissertations. Ames, Iowa: Iowa State University. Retrieved from http://lib. dr.iastate.edu/etd/11508

Huitt, W. (2003). The information processing approach to cognition. Educational Psychology Interactive. Valdosta, GA: Valdosta State University. Retrieved from http://www.edpsycinteractive.org/topics/ cognition/infoproc.html

Johnson, B., \& Christensen, L. (2008). Educational research: quantitative, qualitative and mixed approaches (3nd ed.). California: Sage.

Kusnekoff, J., Munz, S., \& Titsworth, S. (2015). Mobile Phones in the Classroom: Examining the Effects of Texting, Twitter, and Message Content on Student Learning. Communication Education, 64(3), 344-365. doi: http://dx.doi.org/10.1080/03634523.2015.1038727

Lewis, M. (1993). The lexical approach: The state of ELT and the way forward. Hove, England: Language Teaching Pub.

Mansourzadeh, N. (2014). A comparative study of teaching vocabulary through pictures and audio-visual aids to young Iranian EFL learners. Journal of Elementary Education, 24(1), 47-59. Retrieved from http://pu.edu.pk/images/journal/JEE/PDF-Files/3_Nurullah\%20Mansourzadeh_24_1_2014.pdf

Mayer, R. E (2001). Multimedia Learning. NY: Cambridge University Press.

Mayer, R. E., \& Sims, V. K. (1994). For whom is a picture worth a thousand words? Extensions of a DualCoding Theory of multimedia learning. Journal of Educational Psychology, 86(3), 389-401. doi: http://dx.doi.org/10.1037/0022-0663.86.3.389

McCoy, B. R. (2013). Digital distractions in the classroom: student classroom use of digital devices for non-class related purposes. Journal of Media Education, 4(4), 5-14. Retrieved from http:// digitalcommons.unl.edu/journalismfacpub/

McCoy, B. R. (2016). Digital Distractions in the Classroom Phase II: Student Classroom Use of Digital Devices for Non-Class Related Purposes. Journal of Media Education, 7(1), 5-32. Retrieved from http://digitalcommons.unl.edu/journalismfacpub/

McLaughlin, B. (2013). Second language acquisition in childhood: Volume 2: School-age Children. NY and Hove: Psychology Press.

Mistar, I. B., \& Embi, M. A. (2016). Students' perception on the use of whatsapp as a learning tool in ESL classroom. Journal of Education and Social Sciences, 4(June), 96-104. Retrieved from http://jesoc. com/wp-content/uploads/2016/08/Edu-76.pdf

Nation, P. (1995). New Ways in Teaching Vocabulary. TESOL.

Nunnally, J. C., \& Bernstein, I. H. (1994). Psychometric theory (3th ed.). New York: McGraw Hill.

Oblinger, D. G., \& Hagner.P. (2005). Seminar on educating the Net Generation. Presented at EDUCAUSE, Tempe, AZ, August. Retrieved from http://www.educause.edu/section_params/conf/esem052/ OneDayv2-HO.ppt\#3 
Plana, M. G- C., Escofet, M. I. G., Figueras, I. T., Gimeno, A., Appel, C., \& Hopkins, J. (2013, July). Improving learners' reading skills through instant short messages: A sample study using WhatsApp. 4th World-CALL Conference, Glasgow. Retrieved from https://www.researchgate. net/publication/255718202_Improving_learners'_reading_skills_through_instant_short_ messages_a_sample_study_using_WhatsApp

Ryan, G., \& Bernard, H. R. (2000). Data management and analysis methods. In N. Denzin \& Y. Lincoln (Eds.), Handbook of qualitative research (pp. 769-802). Thousand Oaks, CA: Sage.

Sadeghi, K. \& Farzizadeh, B. (2013). The Effect of Visually-Supported Vocabulary Instruction on Beginner EFL Learners' Vocabulary Gain. MEXTESOL Journal, 37(1), 1-12. Retrieved from http:// mextesol.net/journal/public/files/b673cd6a46cfeade6b620fe5bb7f3836.pdf

Sadeghi, K. Khezrlou, S. \& Modirkhameneh, S. (2016). Calling Iranian learners of L2 English: effect of gloss type on lexical retention and reading performance under different learning conditions. Journal of Research in Reading, O(0), 1-21. Retrieved from http://onlinelibrary.wiley.com/doi/10.1111/14679817.12088/epdf

Sanchez-Meca, J., \& Marin-Martinez, F. (2010). Meta Analysis. In P. Peterson, E. Baker \& B. McGaw (Eds.), International Encyclopedia of Education (Vol. 7, pp. 274-282). Oxford: Elsevier.

Sarwar, B., Zulfiqar, S., Aziz, S., \& Chandia, K. E. (2018). Usage of Social Media Tools for Collaborative Learning: The Effect on Learning Success with the Moderating Role of Cyberbullying. Journal of Educational Computing Research. doi: https://doi.org/10.1177/0735633117748415

Smit, I. (2012). WhatsApp with BlackBerry; Can Messengers (BBM) be MXit? In Proceedings of the 14th Annual Conference on World Wide Web Applications. Cape Town, South Africa: Cape Peninsula University of Technology. Retrieved from http://hdl.handle.net/10394/13628

Sylwester, R. A. (1995). A Celebration of Neurons: An Educator's Guide to the Human Brain. ASCD Pub., Alexandria, VA.

Tashakkori, A., \& Teddlie, C. B. (2003). Handbook of mixed methods in social and behavioral research. Thousand Oaks, CA: Sage.

Tavsancil. E., \& Aslan. E. A. (2001). Icerik analizi ve uygulama ornekleri [Content analysis and example applications for oral, written, and other documents]. Ankara: Epsilon Yayinlari.

Ulitsky, H. (2000). Language Learner Strategies with Technology. Journal of Educational Computing Research, 22(3), 285-322. doi: https://doi.org/10.2190/VLTU-CCXF-NFYL-277H

Wilkins, D. A. (1972). Linguistics in language teaching. London: Edward Arnold, p. 111.

Wolcott, H. F. (1990). On seeking-and rejecting-validity in qualitative research. (Ed.) E. W. Eisner, \& A. Peshkin, Qualititative Inquiry in Education the Coutinuing Debate (121-152). NY: Teachers Collage Press.

Wong, L.-H., \& Looi, C.-K. (2010). Vocabulary learning by mobile-assisted authentic content creation and social meaning-making: two case studies. Journal of Computer Assisted Learning, 26(5). doi: http:// dx.doi.org/10.1111/j.1365-2729.2010.00357.x

Vacha-Haase, T. \& Thompson, B. (2004). How to estimate and interpret various effect sizes. Journal of Counseling Psychology, 51(4), 473-481. doi: https://doi.org/10.1037/0022-0167.51.4.473

Van Lier, L. (2014). Interaction in the language curriculum: Awareness, autonomy and authenticity. London, UK: Routledge.

Yildirim, A., \& Simsek, H. (2008). Sosyal bilimlerde nitel arastirma yontemleri (6. Baski) [Qualitative research methods in social sciences (6nd ed.)]. Ankara: Seckin Yayincilik.

Zimmerman, C. B. (1994). Self-selected reading and interactive vocabulary instruction: Knowledge and perceptions of word learning among L2 learners (Order No. 9601089). Retrieved from ProQuest Dissertations \& Theses Global (304107947) Retrieved from https://search.proquest.com/ docview/304107947?accountid=8319 